\title{
FINANCIAL PERFORMANCE OF THE COMPANY BEFORE AND AFTER MERGER
}

\author{
Irfandi ${ }^{\mathrm{a}}$, Bambang Mulyana ${ }^{\mathrm{b} *}$ \\ ${ }^{\mathrm{a}}$ Irfandifan02@gmail.com, ${ }^{\mathrm{b}}$ bambang_mulyana@mecubuana.ac.id \\ ${ }^{a}$ Mercu Buana University, Jakarta
}

\begin{abstract}
This study aims to prove empirically about the company's financial performance, as measured by performance- based financial ratios before and after the merger. The population of this research is non-bank companies that conducted mergers from 2011-2017As many as 10 companies, the research sample was taken by using saturated sampling method so that the sample size was the same as the population. The test tool used to answer the hypothesis is the nonparametric test using the Wilcoxon Signed Ranks Test. The results of this study indicate that in Current Ratio (CR), Debt to Equity Ratio (DER), Return on Assets (ROA), Net Profit Margin (NPM), Total Asset Turn Over (TATO) there are no significant differences before and after the merger. Only Return on Equity (ROE) shows a significant difference before and after the merger.
\end{abstract}

Keywords : Merger, financial performance, Wilcoxon signed ranks test.

\section{Introduction}

The era of globalization requires companies today to be innovative in order to survive in competition with other companies. Such conditions encourage companies to always develop corporate strategies in order to survive or even develop. Strategy development is carried out by the company to maintain its existence. One of the strategic options that companies can choose is to do a business combination. A business combination is the merger of two or more separate companies into an economic entity because one company with another company or obtains control over the assets and operations of another company, the type of business combination can be divided into two, namely acquisition and pooling of ownership which is commonly called a merger (PSAK No.22). According to Putra (2003; 86), companies carry out mergers and acquisitions with the expectation of financial performance joining companies can increase. One of the benchmarks of a company's financial performance is financial ratios. 
Various studies on the results of research have been conducted on the company's financial performance related to corporate actions in the form of mergers, with varying results. In measuring the company's financial performance, this study uses liquidity ratios, solvency, activity, profitability. Liquidity can be measured by current ratio (CR), solvency with debt to equity ratio (DER), activities using total asset turnover (TATO), profitability using net profit margin (NPM), return on assets (ROA), return on equity. (ROE). Study results are not always consistent from one study to another.

Utami (2017) found that there was a difference in the current ratio (CR) before and after the merger, in line with the results of the study by Eni, et al. (2016) in Indonesia and research by Maditinos et.al (2009) in Greece. However, it is different from the results of the study by Setiawan and Rasmini (2018) current Ratio (CR) which has a significance value higher than 0.05 , so it can be said that the two ratios do not experience significant differences, similar to the results of the study by Novaliza and Djajanti (2013) in Indonesia. , and the study of Ahmed and Ahmed (2014) in Pakistan, where the company's liquidity did not increase significantly after the company conducted a merger.

Ekabiakto and Mulyana (2018) in their research found that the debt to equity ratio (DER) increased after a company merger or acquisition compared to before a merger or acquisition. This is in line with the results of the study by Aruna and Nirmala (2013) in India. It is different with the results of the study by Sundari (2017), Larasati et.al (2018) in Indonesia, and Ansari and Mustafa (2018) in India, which found that the debt to equity ratio did not have a significant difference before and after mergers and acquisitions.

Nicky et.al (2018), Pachulia (2018), Nasir (2018), and Kumara and Satyanarayana (2013), in their research found that return on assets (ROA) had a significant effect because the company experienced a significant increase after the merger. This is different from the research results of Ahmed et.al (2018), Sujud and Hachem (2018), Utami (2017), Finansia (2017), and Gunawan and Sukartha (2013) which found that ROA has no significant effect after the merger. On return on equity (ROE), in studies Ekabiakto and Mulyana (2018), Gunawan and Sukharta (2013), and Fitriasari (2016) found that there was a significant increase in ROE compared to before the 
merger or acquisition. However, it is inversely proportional to the results of the study of Sujud and Hachem (2018), Ahmed et.al (2018), Utami (2017), Sundari (2017), there is no significant difference in ROE after the merger.

Net Profit Margin (NPM), in the study of Aruna and Nirmala (2013), found that NPM increased significantly after the merger. Meanwhile, Novaliza and Djajanti (2013) found that there is no significant difference in postmerger NPM. This result is not in accordance with Stevanie (2019) in his study which found that after mergers and acquisitions, NPM decreased due to a decrease in the company's net profit even though the company's revenue had increased.

Total Asset Turn Over (TATO), Eni, et al. (2016) in their study found a significant difference after the merger. This contrasts with Larasati at.al (2017) which shows that there is no significant difference in TATO before and after the merger.

Based on the results of several studies above, the problem in this study is whether the Current Ratio (CR), Debt to Equity Ratio (DER), Return on Assets (ROA), Return on Equity (ROE), Net Profit Margin (NPM), Total Assets Turnover (TATTOO). better than before the merger?

\section{Literature Review}

Merger is a combination of two or more companies which results in one company that will maintain the identity of one of the companies conducting the merger, generally companies that pay attention to identity are the larger companies (Gitman \& Zutter, 2015). Meanwhile, according to IAI PSAK No.22, the form of merging two or more separate companies into one economic entity is because one company merges with another company or gains control over the assets and operations of another company.

Moin (2010: 48) explains, in principle, there are two motives that encourage a company to conduct mergers and acquisitions, namely economic motives and non-economic motives. Economic motives are related to the essence of the company's goals, namely increase the value of the company or maximize the prosperity of shareholders. On the other hand, non-economic motives are motives that are not based on the essence of the company's goals, but are based on 
the subjective desires or personal ambitions of the owner or management of the company. Broadly speaking, the motives for mergers and acquisitions are economic, synergy, diversification, and non-economic motives.

\section{Financial Ratios}

According to Van Horne (Kasmir, 2010: 93), financial ratios are an index that connects two accounting numbers and is obtained by dividing one number by another. Financial ratios are used to evaluate the company's financial condition and performance. From the results of these financial ratios it can be seen the health condition of the company concerned. Commonly used financial ratios to assess a company's financial performance are:

\section{1) Liquidity Ratio}

Fred Weston (Kasmir, 2010: 110), states that the liquidity ratio is a ratio that describes a company's ability to meet short-term obligations (debt). The ratio used is the current ratio (CR), a ratio that shows the company's ability to meet short-term liabilities using current assets, with the following formula:

$\mathrm{CR}=($ Current Assets / Current Liabilities $) \times 100 \%$

\section{2) Solvency Ratio (Leverage)}

The solvency ratio or the leverage ratio is a ratio used to measure the extent to which the company's assets are financed with debt. Debt to Equity Ratio (DER), is a ratio used to assess debt to equity. With the following formula:

DER $=($ Total Debt $/$ Total Equity $) \times 100 \%$

3) Profitability Ratio

Profitability ratio is a ratio to assess the company's ability to seek profits, this ratio also provides a measure of the management effectiveness of a company. with the following three formulas:

$\mathrm{ROA}=($ Income After Interest and Tax / Total Assets $) \times 100 \%$

$\mathrm{ROE}=($ Income After Interest and Tax / Total Equity $) \times 100 \%$ 
4) Activity Ratio

The activity ratio is the ratio used to measure the effectiveness of a company in using its assets. With the following formula:

TATO $=($ Net Sales $/$ Total Assets $)$

\section{Method}

\section{Designs and Samples}

This study uses a comparative design, which is a comparative study, which aims to determine differences in the financial performance of companies before and after the merger. The population in this study were non-bank companies that carried out corporate actions (mergers) in 2011-2017 which were listed on the IDX, DES, ksei.co.id. The sampling technique uses saturated samples, so that all populations are used as samples.

\section{Types and Data Collection Techniques}

This study uses quantitative data with secondary data obtained from IDN Financial, IDX, Sahamok.com, ksei.co.id and other sources using documentation techniques.

\section{Data analysis technique}

This study calculates the company's financial ratios 3 years before the merger, followed by calculating the financial ratios 3 years after the merger, and the average total ratio in each company for years $\mathrm{T}-3, \mathrm{~T}-2$ and $\mathrm{T}-1$. compared with the average years $\mathrm{T}+1, \mathrm{~T}+2$, and $\mathrm{T}-$ 3 to determine performance best.

\section{Normality Test and Hypothesis Test}

The normality test is used to determine the distribution of data in the variables to be used in research with a normal distribution or not, using the Kolmogorov-Smirnov test. To test the hypothesis using the Wilcoxon Signed Ranked Test. 


\section{Results and Discussion}

\section{Normality Test Results}

This is the result of the 3 (three) year variable normality test before and after the merger.

Table 1: Normality Test Results before and after the Merger

\begin{tabular}{|c|c|c|c|}
\hline Period & Variable & $P$ - Value & Conclusion \\
\hline \multirow[t]{6}{*}{ Before } & $\mathrm{CR}$ & 0,204 & Normal \\
\hline & DER & 0,021 & Abnormal* \\
\hline & ROA & 0,455 & Normal \\
\hline & ROE & 0,657 & Normal \\
\hline & NPM & 0,280 & Normal \\
\hline & TATO & 0,643 & Normal \\
\hline \multirow[t]{6}{*}{ After } & $\mathrm{CR}$ & 0,682 & Normal \\
\hline & DER & 0,007 & Abnormal* \\
\hline & ROA & 0,008 & Abnormal* \\
\hline & ROE & 0,000 & Abnormal* \\
\hline & NPM & 0,131 & Normal \\
\hline & TATO & 0,825 & Normal \\
\hline
\end{tabular}

Fig.1: Normality Test Results before and after the Merger, Source: Data processed using SPSS 21

The results of the normality test above indicate that all variables have a significance value above the Kolmogorov-Smirnov significance value, namely 0.05 , which means that the data is not normally distributed. Then the hypothesis testing is done by using non-parametric Wilcoxon analysis, namely the Wilcoxon Signed Ranks Test. 


\section{Wilcoxon Signed Ranks Test}

The following are the results of the Wilcoxon signed ranks test, which aims to determine the results of observing the mean difference between two pairs of samples whether different or not. The company's financial ratios before and after the merger. Measurement of the Wilcoxon signed ranks test used a significance level of $\alpha=5 \%$. The test results for the 7ilcoxon signed ranks test are as shown below:

Table 2: Wilcoxon Signed Ranks Test Results before and after the Merger.

\begin{tabular}{l|cc}
\hline \multicolumn{1}{c}{ VARIABLE } & SIG. (2-TAILED) & CONCLUSION \\
\hline CR PRE \& CR POST & 0,098 & H1 rejected \\
DER PRE \& DER POST & 0,318 & H2 rejected \\
ROA PRE \& ROA POST & 0,393 & H3 rejected \\
ROE PRE \& ROE POST & 0,047 & H4 accepted \\
NPM PRE \& NPM POST & 0,171 & H5 rejected \\
TATO PRE \& TATO POST & 0,797 & H6 rejected \\
\hline
\end{tabular}

Fig.2: Hypothesis test with Wilcoxon signed ranks test, Source: Data processed using SPSS 21

The table above shows that almost all performance parameters are rejected, which means that there is no significant difference in the current ratio, debt to equity ratio, return on assets, total asset turnover, net profit margin after the merger, but the return on equity has a significant difference.

\section{Discussion}

\section{Hypothesis 1}

This study found that the Current Ratio (CR) was not a significant difference between the period before and after the merger. This indicates that the company has not been optimal in using the company's current assets to pay off the company's current debt after the merger. This research is in line with Setiawan and Rasmini (2018) as well as Novaliza and Djajanti (2013) where the CR variable shows that there is no significant difference after the merger. However, it is not in line with Utami (2017) and Eni, et al (2016).

\section{Hypothesis 2}

In the Debt to Equity Ratio (DER) variable, there was an increase after the merger, but it was not significant. This is in line with the results of the study by Sundari (2017) and Larasati et.al 
(2018). However, it is not in line with Ekabiakto and Mulyana (2018) and Aruna and Nirmala (2013) where there has been a significant increase after conducting mergers and acquisitions.

\section{Hypothesis 3}

This study found that the Return on Assets (ROA) variable did not have a significant difference between before and after the merger. This is in line with the study of Sundari (2017), Larasati et.al (2018), and Ansari and Mustafa (2018). However, this is not in line with Nicky et.al (2018), Pachulia (2018), Nasir (2018), and Kumara and Satyanarayana (2013), in their research they found that (ROA) had a significant effect because the company experienced a significant increase after the merger.

\section{Hypothesis 4}

This study found that there was an increase in Return on Equity (ROE) compared to before the merger. This is in line with the results of studies by Ekabiakto and Mulyana (2018), Gunawan and Sukharta (2013), and Fitriasari (2016). However, it is not in line with Sujud and Hachem (2018), Ahmed et.al (2018), Utami (2017), Sundari (2017), Larasati et.al (2018), and Ahmed et.al (2018). However, it is not in line with the results of the studies of Stevanie (2019), Eni, et.al (2016), and Aruna and Nirmala (2013) in their research found that there were differences after the merger.

\section{Hypothesis 5}

This study found that the Net Profit Margin (NPM) variable has increased after the merger but it is not significant. This is in line withNovaliza and Djajanti (2013), Finansia (2017), Larasati et.al (2018), and Ahmed et.al (2018). However, it is not in line with the results of the studies of Stevanie (2019), Eni, et al (2016), and Aruna and Nirmala (2013) in their research which found that there were significant differences after the merger.

\section{Hypothesis 6}

This study found that the Total Asset Turnover (TATO) variable was absent significant differences before and after the merger. This is in line with the results Larasati at.al (2017), and Fitriasari (2016) studies. However, it is not in line with Eni, et al (2016), Setiawan and Rasmini (2018), Ekabiakto and Mulyana (2018), and Finansia (2017) where there are significant differences after the merger.

\section{Conclusion}

The financial performance of the company conducting the merger is measured using tools measuring CR, DER, ROA, NPM, and TATO showed no difference the three years before and after the merger. There are significant differences on the ROE measurement tool three years before and after the company merged. The purpose of conducting a merger to improve financial performance was not achieved. Motive economy that can produce efficiency, and increase the 
company's economy after doing the merger is not a major factor in the company doing merger. There are other considerations such as saving the company from bankruptcy, personal motives or other reasons that cannot be seen immediately the effect on the company's financial performance.

\section{References}

Ahmed, Farhan, Aneeta Manwani, and Shafique Ahmed. 2018. Merger \& acquisition strategy for growth, improved performance and survival in the financial sector. Jurnal Perspektif Pembiayaan Dan Pembangunan Daerah, 5(4), 196-214.

Ahmed, Muhammad dan Zahid Ahmed. 2014. Merger dan Akuisisi: Pengaruh Kinerja Keuangan Lembaga Perbankan Pakistan. Jurnal Penelitian Ilmiah Dasar dan Terapan. Res., 4 (4) 249-259.

Ansari, Md Alam, and M. Mustafa. 2018. An analytical study of impact of merger \& acquisition on financial performance of corporate sector in India. Journal of Management Research and Analysis, 5(2), 113-116.

Aruna, G., \& S. Nirmala. 2013. Financial performance of mergers and acquisitions of select banks in India. International Research Journal of Business and Management, 1(1), 90102.

Ekabiakto, Son and Bambang Mulyana. 2018. Financial Performance and Corporate Value Post Merger and Acquisition (Study On Manufacturing Industry Issuer In Indonesia). International Journal of Engineering Technologies and Management Research, 5(11), 25-33.

Eni, Nur dan Akbar Yusuf. 2016. Perbandingan Kinerja Akutansi Perusahaan Sebelum dan Sesudah Merger dan Akuisisi Yang Terdaftar di Bursa Efek Indonesia. Jurnal Akuntansi Universitas Muhammadiyah Kupang, 3(03), 62-75.

Finansia, Linda. 2017. Analisis Kinerja Keuangan Perusahaan Sebelum dan Setelah Merger dan Akuisisi. Jurnal Manajemen Bisnis Indonesia (JMBI), 6(1), 43-54.

Fitriasari, Faranita. 2016. Analisis Perbandingan Kinerja Keuangan Perusahaan Sebelum Dan Sesudah Merger Dan Akuisisi Terhadap Manajemen Entrenchment (Studi Perusahaan Yang Melakukan Merger Dan Akuisisi yang Terdaftar Di BEI Periode 2011-2013) (Doctoral dissertation, Universitas Muhammadiyah Sidoarjo).

Gitman, Lawrence J., and Chad J. Zutter.2012. Principles of Managerial Finance (ed.). Edinburgh, England: Pearson. 
Gunawan, Kadek Hendra dan I Made Sukartha. 2013. Kinerja pasar dan kinerja sesudah merger dan akuisisi di Bursa Efek Indonesia. E-Jurnal Akuntansi Universitas Udayana Bali.

Kasmir. 2010. Analisis Laporan Keuangan, Cetakan Ke - 3. Jakarta: PT. Rajagrafindo Persada.

Kumara, Manoj dan Satyanarayana. 2013. Studi Banding Pra dan Pasca Integrasi Korporat melalui Merger dan Akuisisi. Jurnal Internasional Bisnis dan Penemuan Manajemen. Vol 2 Edisi 3, hlm. 31-38.

Larasati, Novia Dian, Yuli Agustina, Lulu Nurul Istanti, dan Trisetia Wijijayanti. 2018. Do Merger And Acquisition Affect On Company's Financial Performance?. Sriwijaya International Journal of Dynamic Economics and Business, 1(4), 375-386.

Maditinos, Dimitrios, Theriou Nikolaos G, danDemetriades Efstathios. 2009. The effect of mergers and acquisitions on the performance of companies - the Greek case of IonikiLaiki Bank and Pisteos Bank. European Research Studies Journal, 12(2), 111-130.

Moin, Abdul. 2010. Merger, Akuisisi, \& Divestasi: Edisi Kedua. Yogyakarta: Ekonisia.

Nasir, Munawir. 2018. Analisis Perbandingan Kinerja Keuangan Pada Perusahaan Sebelum dan Sesudah Merger dan Akuisisi (Studi Perusahaan yang Melakukan Merger dan Akuisisi yang Terdaftar di BEI 2013-2015). Jurnal Economic Resource, 1(1), 71-85.

Novaliza, Putri dan Atik Djajanti. 2013. Analisis Pengaruh Merger Dan Akuisisi Terhadap Kinerja Perusahaan Publik Di Indonesia (Periode 2004 - 2011). Jurnal Akuntansi \& Bisnis. Vol.1 No.1;2013.

Pachulia, Olga. 2018. Impact of Mergers and Acquisitions on Corporate Performance: A Case study of Silknet Company. Ecoforum Journal, 7(3).

Putra, I Nyoman Wijana Asmara. (2004). Merger dan Akuisisi: Menambah Manfaat atau Masalah. Vol.9. No. 1, hlm. 86-92.

Putra,Nicky Irawan, Hermanto Siregar dan Suwinto Johan .2018. The Influence Of Mergers And Acquisition On Financial Performance And Stock Return Of Indonesian Banks. European Journal of Accounting, Auditing and Finance Research - Vol.6, No.4, hlm.7994.

Setiawan, I. Putu Doni Aditya, dan Ni Ketut Rasmini. "Analisis Perbandingan Kinerja Keuangan Perusahaan Sebelum dan Sesudah Merger dan Akuisisi Periode 2011-2014." E-Jurnal Akuntansi 24.1 (2018): 687-714.

Stevanie, Bonnie Mindosa. 2019. Dampak Merger \& Akuisisi Pada Kinerja Keuangan: Studi Pada Perusahaan Non Keuangan Yang Terdaftar Di Bursa Efek Indonesia Periode 20122016. Jurnal Manajemen, 8(2). 
Sujud, Hiyam dan Boutheina Hachem. 2018. Effect of mergers and acquisitions on performance of Lebanese banks. International Research Journal of Finance and Economics, 166, 69-77.

Sundari, Retno Ika. 2016. Kinerja Merger dan Akuisisi pada Perusahaan Go Public. Telaah Bisnis, 17(1).

Utami, Anisa Aristanti. 2017. Pengaruh Merger Terhadap Kinerja Keuangan Perusahaan yang Terdaftar di Daftar Efek Syariah (Doctoral dissertation, UIN Raden Intan Lampung). 